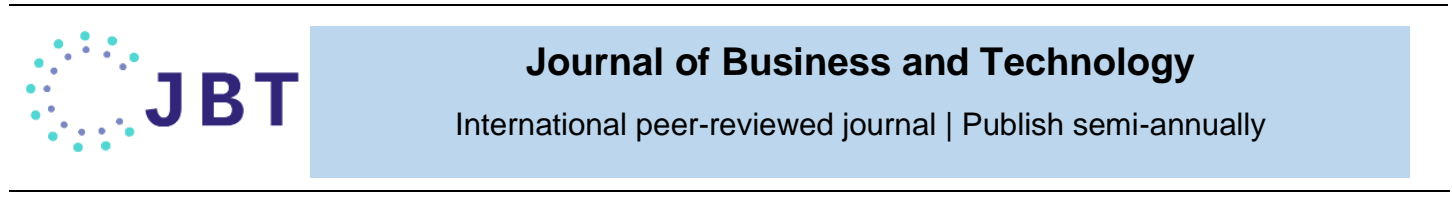

\title{
The Impact of Financial Reporting Quality on Firm Performance
}

\author{
Rathnayake, R.M.S.S. ${ }^{{ }^{*}}$, Rajapakse, R.P.G.S.N. ${ }^{2}$ and Lasantha, S.A.R. ${ }^{3}$ \\ ${ }^{123}$ Department of Commerce and Financial Management, University of Kelaniya, Sri Lanka. \\ * Corresponding Author: sakunika_2019@kln.ac.lk
}

\begin{abstract}
Financial Reporting Quality is the faithfulness of the information conveyed by the financial reporting process. The quality of information is vital for users of financial information. This study aims to examine the impact of Financial Reporting Quality on Firm Performance in listed companies in Sri Lanka. This study uses a quantitative approach. Secondary data was obtained from listed companies' published annual financial statements over six years (2013-2018). The sample consists of 30 listed companies in Sri Lanka from all sectors except Bank, finance, and insurance sector. Thus, the number of observations summed up to 180 in total. Stratified Random sampling method was used to select the sample and the hypothesis has been tested by the random effect model using STATA. Results showed an overall significant relationship for the tested three models where Return of Assets, Return on Equity, and Market to Book Ratio were regressed against Financial Reporting Quality and control variables. However, the relationship between Financial Reporting Quality and individual financial performance indicators was insignificant. Despite the theoretical arguments and empirical findings on the impact of financial reporting quality on financial performance, the study in the Sri Lankan context showed no relationship. This may warrant further research in the area with increased sample size.
\end{abstract}

Keywords: Discretionary Accruals, Financial Reporting Quality, Firm Performance, Market to Book Ratio, Return on Assets, Return on Equity.

\section{INTRODUCTION}

Financial reporting is one of the main processes in an organization that provides valuable information about the company's strategies, past events, and current status to the users of financial statements. According to Jonas and Blanchet (2000), Financial reporting is a process that depends on the quality of each part, such as information and disclosures related to the company's transactions, judgments made by management and also the information about selection and application of accounting policies. By using such information, decision-makers decide whether to invest or not in a particular firm. Further, they decide whether to lend or not to the firm. Most importantly, currently, there is a high demand for quality information by investors, stakeholders and society due to business globalization, geographical expansion and technological advances.
High-quality financial reporting will not result just because it was prepared according to generally accepted accounting policies and standards. Thus, Financial reporting quality refers to the characteristics of a firm's financial statements. As per the Conceptual framework for financial reporting-ICASL (2020), Highquality financial reporting must be helpful in decision making. Relevance and faithful representation are the two characteristics of decision-useful financial reporting. Relevance of the financial information is capable of making a difference in decisions made by the users. Financial information is capable of making a difference in decisions if it has predictive value, conformity value or both. Also, to be helpful, financial information must not only represent relevant phenomena, but it must also faithfully represent the phenomena that it purports to represent. 
Quality of financial reporting may affect a companies' profitability, Liquidity, Efficiency, Stock prices, users' decisions, and company performance. Therefore, firms need to identify the impact of financial reporting quality on those aspects. Also, information asymmetries will be reduced because greater transparency is a result of this high-quality information. This leads to satisfying investors' and stakeholders' needs. (Martínez-Ferrero, 2014).

Financial reporting quality will be lower by the discretionary behavior and decisions taken by management. They may attempt to manipulate financial information for different purposes. It will eliminate the fundamental characteristic of reporting quality, which is the faithful representation and ultimately affect the firm's financial performance. Hence, the focus should be given to the financial numbers in statements and the qualitative side.

According to previous studies, mainly employed proxy can be identified as earnings quality to assess financial reporting quality. It is crucial to consider that Earnings quality is negatively associated with earnings management, which is considered to be the inverse of Financial Reporting Quality (FRQ); higher earnings management lowers the financial reporting quality (Dechow and Dichev, 2002). Earning management is a strategy used by the company's management to manipulate the company's earnings. Therefore, it may not represent the accurate picture of financial statements and mislead the users. Thus, financial reporting quality will lower when there is a high degree of earnings management. Those unethical practices may use by management mainly to increase firm financial performance.

According to Dashtbayaz, Hedayatipour \& Molaviwas (2018), no relationship was found between Financial Reporting Quality and Corporate performance in the Iran context.

Moshi (2016) and Ezeagba (2018) found an insignificant relationship with discretionary accruals, which is the measurement of Financial Reporting Quality and firm performance.
However, even though many international researchers conducted studies regarding the Financial Reporting Quality, Sri Lanka has insufficient previous studies. Those studies were focused mainly on assessing the relationship between IFRS adoption, Audit committee, Audit Quality and financial reporting quality (Perera, 2019 ; Weerathunga, 2015; Pakianathan, 2017; Shantha, 2015).

The above arguments are directed to identify the impact of financial reporting quality on firm performance. This study mainly focuses on measuring the financial performance of the firms using Return on Assets (ROA) Return on Equity (ROE), and Market to Book ratio (MTB). After determining the relationship between firm performance and financial reporting quality, it will enable us to identify the impact when a firm generates quality information and what will result from not having quality information to the decisionmakers. Therefore, this study is conducted to identify the impact of financial reporting quality on firm performance in the Sri Lankan context by gathering data from listed companies of Colombo Stock Exchange, which is an area with a lack of attention given by researchers in Sri Lanka.

\section{LITERATURE REVIEW}

This section initially details broader theories relating to establishing the relationship between Financial Reporting Quality and Firm Performance. Moreover, it describes related concepts such as Earnings Management and Information Asymmetry. Empirical evidence for the link between financial reporting quality $\&$ firm performance is also provided.

\section{Theories}

Agency theory can be described as the most relevant and most used theory to explain Financial Reporting Quality. The departure of ownership from management in modern corporations provides the perspective for the function of agency theory. The separation between ownership and control generates the probability for clashes of interest between agents and principals, which result in costs (Toukabri et al., 2014). Also, the agency 
relationship leads to the information asymmetry problem because managers can access information more than shareholders (Asegdew, 2016)

The stakeholder's theory is based on the notion that the organization's effectiveness is measured by its ability to satisfy both the agents and shareholders who have a stake in the organization (Matundura, 2014). However, agents in a firm who are the managers of the firms are expected to serve and meet the demands of shareholders who are the owners of the firms (Oluoch, 2014). Stakeholder theory requires the board to serve the interests of shareholders and the interests of related parties.

Financial reporting quality, information asymmetry and earnings management

Quality and accurate financial reporting is considered an effective tool for evaluating organisations' performance, strategies, future status, etc. It can be identified as the primary source for the decision-making process of users.

Usually, organisations prepare financial statements following generally accepted accounting policies. Nevertheless, users cannot ensure that the provided information comprises the main qualitative characteristics such as relevance, Faithful representation, transparency and reliability. Thus, Financial Reporting Quality (FRQ) can be defined as the faithfulness of the information conveyed by the financial reporting process (MartínezFerrero, 2014).

Numerous advantages of providing highquality information have been cited: FRQ reduces information risk and liquidity (Lambert et al., 2007), prevents managers from using discretionary power for their benefit and helps them make efficient investment decisions (Chen et al., 2011). Specifically, one of the main benefits of better FRQ is the minimization of asymmetric information problems that arise from conflicting agencies (Rajgopal and Venkatachalam, 2011).

Companies that report higher quality financial information give the various markets' agents better information, allowing them to act in the market with better conditions and a higher level of information (Jo and Kim, 2007).

Richardson (1998) states that there is information only available for the organization's managers that shareholders cannot access. This is referred to as "information asymmetry." This asymmetry can manifest itself in the form of financial reports published by a firm. Information asymmetries will be reduced because greater transparency and greater transparency result from this highquality information, satisfying investors' and other stakeholders' needs. (Martínez-Ferrero, 2014). Rajgopal and Venkatachalam (2011) add that high-quality financial reporting reduces the lack of equivalence and the asymmetric information that arises from the conflicting agency.

This constructs an information asymmetry in that managers can exercise their discretion on accruals, which reduces the relevance and reliability of reported earnings and the whole financial statement, which ultimately affects the quality of financial reporting. However, by nature, every person is self-interested. Thus, the exact thing can be expected from managers of the organisations, who prepare financial statements. Managers are usually motivated by their improvements rather than considering shareholders' interests and maximizing shareholder value (Atu et al., 2016).

Therefore, management deliberately manipulates the earnings and other financial elements of financial reports to increase their rewards with the company's performance.

When information asymmetry is high, stakeholders are unable to verify whether the published information represents the actual economic condition of the firm or not. This may lead to earnings management. As stated by Dechow \& Skinner (2000) and Schipper (1989) defines earnings management as a purposeful intervention in the external financial reporting process, with the intent of obtaining some private gain. Also, it can be defined as the deliberate misinterpretation of 
the financial condition of an enterprise through intentional misstatement or omission of amounts or disclosures in the financial statements to deceive financial statement users. Earnings management is negatively associated with earnings quality which is a primarily used measurement of financial reporting quality.

\section{The link between financial reporting quality and firm performance}

Financial information issued by a company has become an essential resource for any market participant since it provides a reduced amount of information asymmetries between managers, investors, regulatory agencies, society and other stakeholders. Therefore, the question arises, the impact of financial reporting quality on firm performance.

Furthermore, firm performance can be influenced by the discretional manager behavior through the strategic management process. Thus, it is necessary to know not only the manager's actions, decisions and behavior, but also the corporate strategy and accounting policies among others, to highlight the causes of a firm's performance. (Martínez-Ferrero, 2014). According to Lee et al. (2006), corporate performance and growth determine the quality of financial information reported by companies.

According to Lopes (2012), there is an inverse relationship between financial reporting quality and financial performance in European countries. Return of Assets (ROA) and Return of Equity (ROE) increased when positive Abnormal Accruals (AA) increased and decreased when negative AA became more negative.

For this study, data were collected from 17 European countries for ten years. Abnormal Accruals are employed as the proxy to measure financial reporting quality. ROA and ROE were used to measure financial performance.

Companies resulted in higher performance when their Provided financial information are in a certain standard of better quality, due to the fact that the market positively assesses those companies which are more dedicated to the issuance of good Information for shareholders and other stakeholders (GarcíaLara et al., 2010 ; Ahmed \& Duellmand, 2011; Bushman \& Smith, 2001; Bens et al., 2002; Gunny, 2005).

A study of the relationship between reporting quality and financial performance of companies listed at the Nairobi security exchange was carried out by Ouma. 2017). This study concludes that the effect of financial reporting quality on financial performance is positive and significant. This means greater the degree of financial reporting quality, the greater the propensity of a firm making substantial net profit margins.

Also, it is necessary to highlight the work of McDemmott (2011), who shows how higher quality financial statements improve the efficiency of investments in CSR because FRQ mitigates moral hazard problems. This leads to a CSR investment that benefits not only stakeholders but also investors, a key factor that determines future improved performance. Chen (2011) finds that both banks and government can benefit from having highquality financial reporting because it has a positive effect on private firms' investment efficiency and financial performance, increasing tax payment and lending from banks.

A study done by Nnadi (2013) reported a negative relationship between Financial Reporting Quality and Firm Performance. In this study, financial reporting standards were evaluated using an earnings management metric approach over ten years.

Moshi (2016) showed that return on asset has an insignificant positive association with earning management measured by discretionary accruals in manufacturing companies listed at the Dar-es-salaam stock exchange market under correlation and regression analysis.

A Kenyan perspective on the effect of Financial Reporting Quality on performance was carried out by King'wara (2015). Findings from this study revealed that financial 
reporting quality has a significant influence on the firm's performance. The sample of the study consists of listed companies from 1994 to 2003 and a comparative analysis was carried out before and after implementation of IFRS.

Morris, Susilwati and Gray (2012) did an Asian comparative analysis for Quality Financial Reporting and Financial Performance. This study was conducted for the period of 2002 to 2007. Simple Random sampling was used to get 262 companies listed in Asian countries. Findings of the study reveal that quality financial reporting improved performance which did not differ only with the time but also with the country. Hassan and Bello (2013) conclude that the larger and levered firms in the Nigerian manufacturing sector are less likely to manage earnings and manipulate sales. In addition, it is concluded that profitability is positively associated with earnings quality which is the measure of Financial Reporting Quality. Bushman and Smith (2001) also report that companies could enjoy a rise in their corporate performance due to the fact that higher financial reporting quality is bound to promote profitable investment decisions.

According to Nijam (2016), firms' size and profitability are significantly and positively associated with the perceived impact of IFRS on firms' quality of financial reporting and corporate governance. The purpose of the study was to examine the perceived effect of IFRS adoption and whether it relates to firms' characteristics. Also, Ezeagba (2018) states that earnings management which is the inverse of Financial Reporting Quality, has a negative but insignificant effect on the performance of corporate firms, which was estimated by Return on Shareholders' Fund (ROSF), return on capital employed, net profit after tax and return on assets.

\section{Financial reporting quality and market performance}

Martínez-Ferrero (2014) showed that companies produce higher financial performance when financial statements are reported with high-quality information. This study examines the relationship using three proxies such as the earnings quality, conservatism and accruals quality. Financial performance measure using the market to book ratio.

According to a study on corporate governance, reporting quality, and firm value: evidence from Indonesia carried out by Ferdinand et al. (2013) found a negative association between reporting quality and the proxies for firm value. These findings indicate that lower value firms tend to disclose more information than higher value firms. Firm value was measured using Tobin's Q and ROA.

Lin et al. (2014) researched on "Does highquality financial reporting mitigate the negative impact on global financial crises on firm performance, evidence from the UK". Researchers tried to examine the impact of the quality of financial reporting (as measured via earnings quality) on liquidity in the equity market. The research concludes that firms with high-quality financial reporting suffered fewer negative effects due to the financial crises.

Mironiuc et al. (2015), \& Mihai \& Chersan (2015) researched the relevance of financial reporting on the performance of quoted Romanian companies in the context of adopting the IFRS. For this study, the sample of 65 companies quoted in the Bucharest Stock Exchange was tested. This paper also empirically analyses the influence of Big 4 companies to improve the relevance of the reporting of the net income and the comprehensive income for the investors on the financial market. The study results confirm that the two categories of accounting results are significantly associated with the share price, reflecting an increased value relevance and usefulness for the investors on the Romanian financial market.

\section{Evidence from Sri Lankan context}

A study on the impact of IFRS adoption on accounting quality in Sri Lanka which is conducted by Weerathunga (2015) concluded that the Accounting Quality of Sri Lankan firms improved after mandatory IFRS adoption in terms of displaying less 
management towards earnings targets and more timeliness of loss recognition. In addition, results revealed that Earnings smoothing had increased significantly following the mandatory adoption of IFRS.

Also, Yasas and Perera (2019) conduct a study on the impact of IFRS Adoption on the quality of accounting Information. However, there is no clear evidence that IFRS adoption enhances the quality of accounting information pertaining to Sri Lankan context.

This study employs 29 listed manufacturing companies with pre-IFRS (2009-2011) and post-IFRS (2013-2015) information. Data were analyzed using the multiple regression method. Results showed that the value relevance of accounting information has not significantly improved in the post-IFRS period than the pre-IFRS period.

A study done by Kankanamage and Shantha (2015), examines the impact of audit committee characteristics on financial reporting quality in Sri Lanka from 2012-2015. The financial reporting quality is measured using Kothari, Lenon \& Wesley (2005) performance-adjusted discretionary accrual model. The results show a strong negative relationship between audit committee characteristics and financial reporting quality in Sri Lankan listed firms.

\section{METHODOLOGY}

This section consists of conceptual framework, variables, population and sample, data collection, operationalization and analytical technique.

The study adopted a quantitative approach and to examine the relationship; secondary data were collected from annual reports. The population of the study includes all listed companies in Colombo Stock Exchange. The sample of this study consists of 30 listed companies in Sri Lanka by covering all the sectors except banking, insurance and financial institutions. Banking, insurance, and financial institutions are exempted from the sample because the Central Bank of Sri Lanka governs these institutes' under special laws, regulations, and restrictions. A stratified random sampling technique has been used to draw the sample.

Data had been collected over six years which covers the period of 2013 to 2018 . The reason for time period consideration without taking years after 2019 is to avoid the misinterpretation of data due to the impact of COVID-19 pandemic.

Financial Reporting Quality, the independent variable of this study measured using an Equity quality proxy. Equity quality is the inverse of earnings management which is the deliberate manipulations done by the management of the company. Earnings management is measured by discretionary accruals using kothari model. Firm performance, which is the dependent variable of this study is evaluated by Return on Assets (ROA), Return on Equity (ROE) and Market to book ratio (MTB). Leverage, Risk and Big4firms are the control variables of the study.

Analysis techniques can be identified as descriptive statistics, Panel data regression analysis which was performed using STATA software 14.2 version

\section{Variables}

Table 1: Operationalization of variables

\begin{tabular}{|c|c|c|}
\hline Variable & Measurement & Source \\
\hline $\begin{array}{l}\text { Financial } \\
\text { Reporting } \\
\text { Quality }\end{array}$ & $\begin{array}{l}\text { Equity quality } \\
\text { measured through } \\
\text { Discretionary } \\
\text { accruals }\end{array}$ & $\begin{array}{l}\text { Martínez-Ferrero } \\
\text { (2014), Kankanamage } \\
\text { C. A, (2015), Moshi.J } \\
\text { (2016), C. Ezeagba } \\
\text { (2018), Shireenjit K. } \\
\text { (2013) }\end{array}$ \\
\hline $\begin{array}{l}\text { Firm } \\
\text { Performanc } \\
\text { e }\end{array}$ & $\begin{array}{l}\text { Return on Assets, } \\
\text { Return on Equity and } \\
\text { Market to Book Ratio }\end{array}$ & $\begin{array}{l}\text { Martínez-Ferrero } \\
(2014), \quad \text { Lopes, C. } \\
(2012)\end{array}$ \\
\hline Leverage & Debt to Equity Ratio & $\begin{array}{l}\text { (Prior et al., 2008; } \\
\text { Mahoney et al., 2008) }\end{array}$ \\
\hline Risk & Beta & $\begin{array}{l}\text { Waddock and Graves } \\
\text { (1997) }\end{array}$ \\
\hline Big4 Firms & Categorical variable & $\begin{array}{ll}\text { Lopes.C., } & \text { (2012), } \\
\text { Bradshaw } & (2014), \\
\text { Mitton, (2002) }\end{array}$ \\
\hline
\end{tabular}




\section{Financial Reporting Quality}

According to the Conceptual Framework for Financial Reporting (2020), the quality of Financial Reporting is mainly evaluated by its fundamental characteristics: Relevance and Faithful Representation. Hence, Financial Reporting quality can be distinct as the faithfulness of the information borne by the financial reporting process. (Martínez-Ferrero, 2014).

The independent variable of this study is Financial Reporting Quality which is measured using Earnings quality. Earnings Quality (EQ) can be identified as one of the most employed proxies of FRQ (MartínezFerrero, 2014).
Ezeagba (2018); Shireenjit (2013) and many other scholars in order to measure the Financial reporting quality/ Equity quality. The Discretionary Accruals Adjustment (DAA) obtain by deducting the Non-discretionary component of accruals (which will be calculated using Kothari model) from the Total Accruals Adjustment (TAA).

Kothari et al. (2005), performance-matched discretionary accruals model applied to detect the discretionary accruals of the firms and the following formula was used to calculate the Total Accrual adjustment.

The Kothari et al. (2005) model uses the following procedure to separate the discretionary from the non-discretionary component.

$$
\frac{\mathrm{TAA}_{i t}}{\mathrm{~A}_{i t-1}}=\beta_{0}+\beta_{1}\left(\frac{1}{\mathrm{~A}_{i t-1}}\right)+\beta_{2}\left(\frac{\Delta(\mathrm{Sales}-\mathrm{AR})_{i t}}{\mathrm{~A}_{i t-1}}\right)+\beta_{3}\left(\frac{\mathrm{PPE}_{i t}}{\mathrm{~A}_{i t-1}}\right)+\beta_{4}\left(\frac{\mathrm{ROA}_{\mathrm{it}}}{\mathrm{A}_{i t-1}}\right)+\mu_{i t}
$$

This measures the degree of earnings management through accruals. Earnings management is a strategy used by the management of a firm to manipulate its earnings to achieve its goals related to the firm's performance. However, it is vital to consider that Earnings Quality and earnings management have an inverse relationship (Dechow \& Dichev, 2002). Higher earning management lowers the earnings quality and financial reporting quality (Raman, 2012).

Therefore, FRQ can be measured through management discretion on accruals (Choi and Pae, 2011). The discretionary component of accruals adjustment could be used to measure discretionary management, which represents accounting manipulation. Kothari model (Kothari et al., 2005) was used to separate the non-discretionary component of accruals from the discretionary one since all accruals are not discretionary. This separation supports to determine the existence and extent of Earnings Management (Garcia, 2005).

This model has been used by many scholars such as Martínez-Ferrero (2014); Kankanamage (2015); Moshi (2016);
TAA $i t=$ total accrual adjustments,

A $i, t-1=$ total assets of firm $i$ in period $\mathrm{t}-1$ and this is used as a deflator to correct possible problems of heteroscedasticity, $\Delta$ Sales $i t=$ change in sales for firm $i$ in period $\mathrm{t}, \Delta \mathrm{AR}$ it $=$ change in Accounts Receivables for firm $i$ in period $\mathrm{t}, \mathrm{ROA}=$ Return on Assets, $\mu$ it $=$ Unexpected components of Accruals (DAA), $\beta 1, \beta 2, \beta 3, \beta 4=$ Firm specific parameters calculated by the OLS regression model.

\section{Firm Performance}

The dependent variable of this study is firm performance. As there are numerous measures to evaluate financial performance, this study uses three measures: Return of Assets (ROA), Return on Equity (ROE), and Market to Book Ratio. Firm performance generally can be divided into financial performance and market performance.

ROA and ROE measure the return generated from the assets and equity employed by a firm which measures the financial performance of the firm. These ratios are easy to obtain and make it possible to compare firms of different sizes (Lopes, 2012). 
Market to Book Ratio (MTB) identifies market measures of Financial Performance according to prior evidence from Hillman and Keim (2001). These authors argue that accounting actions are less successful than market actions because they cannot capture the company's long-term value focused on past performance and are subjected to the possibility of manager manipulation. MTB is measured using the following formula: market capitalization (Market Value of the firm) divided by the total Book value of the firm.

This study also uses control variables such as leverage, risk, and Big4 firms employed by previous studies (Martínez-Ferrero, 2014; Lopes, 2012).

\section{Hypotheses development}

The following hypotheses were constructed based on research problems and objectives to examine the relationship between Financial Reporting Quality and Firm Performance in Sri Lankan context.

$\mathrm{H1}$ : There is a significant impact from Financial Reporting Quality on Return on Equity

$\mathrm{H} 2$ : There is a significant impact from Financial Reporting Quality on Market to Book Ratio

H3: There is a significant impact from Financial Reporting Quality on Return on Assets

\section{Model specification}

In this study, the below-stated standard regression models have been used to understand and measure the direct relationship between Financial Reporting Quality and Firm Performance.

\section{Model 1}

ROE it $=\boldsymbol{\beta} 0+\boldsymbol{\beta} 1 \mathrm{FRQit}+\boldsymbol{\beta} 2 \mathrm{RISKit}+$ $\boldsymbol{\beta} 3$ LEVit $+\boldsymbol{\beta}$ 4BIG4Firmsit $+\boldsymbol{\varepsilon}$

$\boldsymbol{\beta} 0$ is the intercept; other $\boldsymbol{\beta}$ explains the slope coefficients and $\boldsymbol{\varepsilon}$ represents the error component. ROE it is Return on Equity, the dependent variable of this model, which measures the firm performance for firm $i$ in period $t$. Risk, Leverage and Big4firms are the control variables of the model.

\section{Model 2}

$M T B$ it $=\boldsymbol{\beta} 0+\boldsymbol{\beta} 1 \mathrm{FRQit}+\boldsymbol{\beta}$ RISKit + $\boldsymbol{\beta} 3$ LEVit $+\boldsymbol{\beta}$ 4BIG4Firmsit $+\boldsymbol{\varepsilon}$

Model 2 uses Market to Book ratio in order to measure Firm Performance which is the dependent variable of this study. Thus, MTBit represent Market to Book ratio for firm $i$ in period $t$.

\section{Model 3}

ROA it $=\boldsymbol{\beta} 0+\boldsymbol{\beta} 1 \mathrm{FRQit}+\boldsymbol{\beta} 2 \mathrm{RISKit}+$ $\boldsymbol{\beta} 3 \mathrm{LEVit}+\boldsymbol{\beta} 4 \mathrm{BIG} 4 \mathrm{Firmsit}+\boldsymbol{\varepsilon}$

Final model, Model 3 dependent variable is Return on Assets which measures the Firm Performance. ROAit represent the Return on Assets for firm $i$ in period $t$.

\section{DATA ANALYSIS}

This section will forward the results obtained by analyzing the secondary data gathered from the published annual reports of listed companies in Sri Lanka and fill the gap in the literature.

\section{Descriptive statistics}

Table 2: Descriptive statistics

\begin{tabular}{lllll}
\hline Variable & Maximum & Minimum & Mean & $\begin{array}{l}\text { Standard } \\
\text { Deviation }\end{array}$ \\
\hline ROE & $237 \%$ & $-45 \%$ & $11.6 \%$ & $26 \%$ \\
MTB & 8.82 & 0.32 & 2.07 & 1.73 \\
ROA & $39.3 \%$ & $-5 \%$ & $8.7 \%$ & $71.4 \%$ \\
DA & 0.56 & 0.36 & 3.33 & $9.8 \%$ \\
RISK & 6.7 & -1.03 & 1.34 & 4.36 \\
LEV & $724 \%$ & 0 & $57.4 \%$ & $88 \%$ \\
EY & 1 & 0 & $46.7 \%$ & $50 \%$ \\
KPMG & 1 & 0 & $36.7 \%$ & $48 \%$ \\
PWC & 1 & 0 & $13.3 \%$ & $34 \%$ \\
\hline
\end{tabular}

Dependent variables of all three models are ROE, MTB and ROA and total observations were summed up to 180 . According to the Table 2, the dependent variable of model 1- 
ROE shows a mean value of $11.6 \%$ with a Standard deviation of 26\%. Model 2, the dependent variable, the Market to Book value ratio, denotes a mean value of 2.07 , meaning that the examined companies are generally positively assessed for the market. They have a higher assessment than their book value. Also, this represents a minimum value of 0.32 and a maximum value of 8.82 . The dependent variable of Model 3 ROA shows $8.7 \%$ of a mean value with a minimum value of $-5 \%$ and a maximum value of $39 \%$. The standard deviation of this is $71.4 \%$.

When analyzing the independent variable, the mean value of Discretionary Accruals (DA), the measure of FRQ, resulted in 3.33 while it ranges from $-36.4 \%$ to $56 \%$ with a standard deviation of $9.8 \%$.

\section{Panel data regression analysis model}

The fixed effect is not suitable for this study as there is a categorical variable called Big4firm. Thus, Breusch and Pagan Lagrangian multiplier test (LM Test) is used to test the most suitable model between Pooled OLS and random-effect model. According to the results for all the models, it was $\sigma \mu 2=0$.

Therefore, data cannot be pooled and the random effect model is preferred over the pooled OLS model.

\section{Testing regression assumptions}

Model 01 and Model 03 are Normally distributed as per the results of the Kernal Density Estimate (Figure 1, 2). According to the results, the values are range between +2 and -2 . Thus, it can be concluded that the variables are approximately distributed normally.

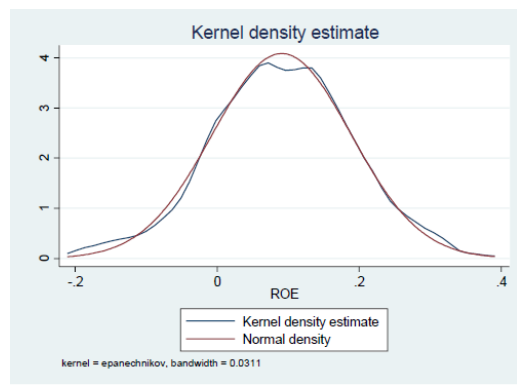

Figure 1: Normality test: Model 01 Return on Equity

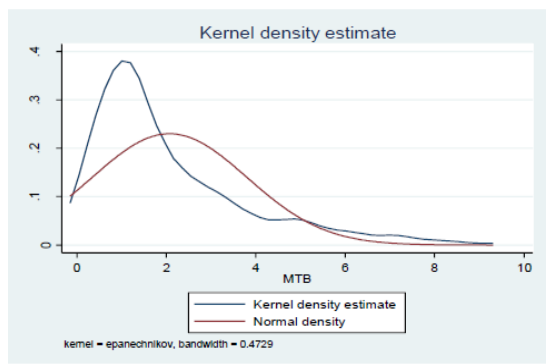

Figure 2: Normality test: Model 02 Market to Book Ratio

According to figure 3 , it does not appear as a bell-shaped curve. Thus, it cannot be confidently concluded that the data is normally distributed.

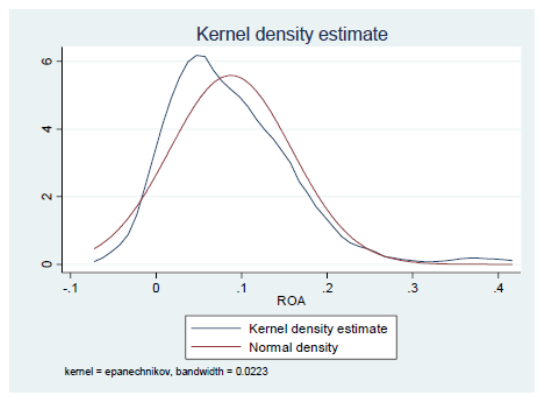

Figure 3: Normality test: Model 03 - Return on Asset

Transformation of data into log can be identified as a solution for the normality issue in Model 03. Thus, using STATA the variable was transformed into $\log$ and retested. Refer following results in figure 4 with logged variable. 


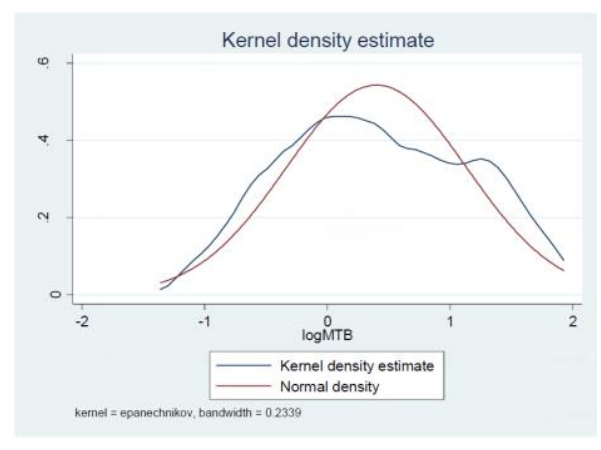

Figure 4: Adjusted Normality test: Model 03 - Return on Asset

Table 3: Multicollinearity test- Correlation Matrix

\begin{tabular}{lccccc}
\hline & 1 & 2 & 3 & 4 & 5 \\
\hline 1. DA & 1.0000 & & & & \\
2.LEV & 0.0444 & 1.0000 & & & \\
3.RISK & 0.2261 & 0.0395 & 1.0000 & & \\
4.EY & -0.1811 & -0.1939 & -0.0808 & 1.0000 & \\
5.PWC & 0.0104 & -0.0382 & 0.0127 & -0.3669 & 1.0000 \\
\hline
\end{tabular}

To identify multicollinearity, a correlation test can be used. Pearson correlation analysis was performed to determine the relationships between independent and control variables in order to identify whether they are highly correlated. The correlation coefficients between the variables shown in Table 3 are less than 0.6. hence, it can be concluded that the relationship between variables is not strong, and no multicollinearity issue was detected.

This study used the Wald test in order to identify heteroskedasticity. Accordingly, the results generated for three dependent variables are summarized in Table 4.

Table 4: Heteroskedasticity test

\begin{tabular}{llll}
\hline & Model 1 & Model 2 & Model 3 \\
\hline $\begin{array}{l}\text { P-value } \\
\text { Chi2(30) }\end{array}$ & 0.000 & 0.000 & 0.000 \\
\hline
\end{tabular}

The results show that for all three models, there is a heteroscedasticity problem as the Probability value is less than 0.05 under the
Wald test results.

Wooldridge test for autocorrelation in panel data was performed to test serial correlation

Table 5: Serial Correlation test

\begin{tabular}{llll}
\hline & Model 1 & Model 2 & Model 3 \\
\hline $\begin{array}{l}\text { Prob }> \\
\text { F }\end{array}$ & 0.0306 & 0.0003 & 0.5860 \\
\hline
\end{tabular}

The above results presented in Table 5 show a presence of autocorrelation for model 1 and model 2 as the probability $>\mathrm{F}$ is less than 0.05 , which is significant. However, Model 3 has a Probability value of more than 0.05 , which indicates no Auto Correlation.

Table 6: Cross-Sectional Dependence test

\begin{tabular}{llll} 
& Model & Model & Model \\
1 & 2 & 3 \\
\hline $\mathrm{P}$ & 0.8935 & 0.0000 & 0.9265 \\
Value & & & \\
\hline
\end{tabular}

According to the results, Model 1 and Model 3 despites no cross-sectional dependence as the $\mathrm{p}$-value $>0.05$. However, $2^{\text {nd }}$ model has a cross-sectional dependence according to the results from Persaran test as the $\mathrm{P}$-value $<0.05$. Since this has been violated with a pvalue $<0.05$, then the problem needs to be addressed. Hence, Driscoll and Kraay Standard errors test was used.

As a remedy for both Heteroscedasticity and Autocorrelation, cluster option can be used. Cluster option addresses both issues of heteroskedasticity and serial correlation. As presented above Model 1 indicates heteroscedasticity and Auto Correlation problem. Thus, as the remedy cluster option has been performed whereas according to the above results, it indicates no autocorrelation for model 3. This may be probably because the value is more than 0.05 . Therefore, robust option will be the final output of this model. Though the final outputs of models 1 and 3 were sorted, Model 2 needs to use another remedy to address the final diagnostic test, Cross-section dependence. Thus, the Final output of Model 2 is obtained from Driscoll and Kraay Standard errors test. 
In summary, it can be explained as to obtain the final results for model 1cluster option was used as mentioned above. For model 2 and 3 Driscoll and Kraay Standard errors test and Robust option were used respectively according to the results gained from above diagnostic tests.

\section{Panel data regression analysis}

Table 7: Panel Data Regression Analysis performance (ROE) under the first model.

In terms of control variables such as Debt to Equity ratio and PWC audit firm have a significant relationship with ROE representing 0.027 and 0.02, respectively. However, EY audit firm and Risk (Beta) have an insignificant relationship with ROE by having $P$ values of 0.217 and 0.077 , respectively. According to the results, all the control variables have a negative relationship with

\begin{tabular}{|c|c|c|c|c|c|c|c|c|c|}
\hline & \multicolumn{3}{|c|}{ Model 1} & \multicolumn{3}{|c|}{ Model 2} & \multicolumn{3}{|c|}{ Model 3} \\
\hline & Coeffi. & $\mathbf{Z}$ & $\mathbf{P}$ & Coeffi. & $\mathbf{Z}$ & $\mathbf{P}$ & Coeffi. & $\mathbf{Z}$ & $\mathbf{P}$ \\
\hline $\mathrm{DA}$ & -.024 & -0.24 & 0.81 & -.738 & -0.68 & 0.499 & .045 & 1.34 & 0.182 \\
\hline Risk & -.030 & -1.77 & 0.07 & -.078 & -0.45 & 0.649 & -.018 & -2.22 & 0.026 \\
\hline Lev & -.030 & -2.21 & 0.02 & .015 & 0.36 & 0.722 & -.001 & -2.62 & 0.009 \\
\hline EY & -.076 & -1.24 & 0.21 & -.308 & -2.53 & 0.011 & .028 & 1.78 & 0.075 \\
\hline PWC & -.122 & -2.33 & 0.02 & -1.161 & -10.0 & 0.000 & .001 & 0.05 & 0.958 \\
\hline Const & .214 & 2.76 & 0.006 & 2.435 & 9.34 & 0.00 & .085 & 6.62 & 0.000 \\
\hline $\mathrm{R}^{2}$ & 0.0328 & & & 0.0515 & & & 0.1412 & & \\
\hline $\begin{array}{l}\text { Prob } \\
>\mathrm{F}\end{array}$ & 0.0001 & & & 0.0000 & & & 0.0016 & & \\
\hline $\mathrm{N}$ & 180 & & & 180 & & & 180 & & \\
\hline
\end{tabular}

As per the Table 7, the $\mathrm{P}$ value can be considered to identify the relationships and accept or reject hypotheses. As per results of Model 1 under $95 \%$ of confidence level, the Overall model of the study is significant since it is below the standard significance level of 0.05 . According to model 1 , it represents Probability>chi2 value of 0.0001 .

The overall $\mathrm{R}$ square value of model 1 (ROE) is $3 \%$; this statistically measures the proportion of the variance for Financial reporting quality explained by model 1 .

The independent variable of model 01, discretionary accruals, has a value of 0.8 , which is higher than 0.05 thus, statistically insignificant. When considering the coefficient of the variable, it is -0.024 , which represents a negative relationship with ROE, meaning that discretionary accruals are negatively associated with Return on Equity. That implies that financial reporting quality which is the inverse of Earnings management (Discretionary accruals), showed an insignificant negative relationship with Firm
ROE.

When considering the regression results of model 2 related to relationship between financial reporting quality and Firm performance measured by Market to Book ratio, the overall model indicates a significant relationship by having a p-value of 0.000 and with a R-square value of 5\% which is likely to explain more of the dependent variable than the first model. However, discretionary accruals with a p-value of 0.49 and $z$ value of 0.68 is deliberated an insignificant relationship with the Market to Book ratio. When considering about the coefficient value it indicates a value of -0.738 which is an inverse relationship.

This implies that when discretionary accruals increasing MTB ratio is tend to reduce. Thus, can conclude second model is also insignificant with Financial reporting Quality. In terms of control variables, Beta which is the measurement of risk, has an insignificant negative relationship with MTB ratio and also leverage indicates a weak positive relationship. 
MTB ratio tend to increase with the increment in debt to equity ratio while beta is reducing. However, presence of EY and PWC audit firm has a significant impact to MTB ratio. P-values of Beta, Leverage, EY and PWC are 0.649, $0.722,0.011$ and 0.00 respectively.

According to Model 3, which measures the firm performance through the Return on Assets ratio also shows an overall significance by having a p-value of 0.0016 . Also, this model has an $\mathrm{R}^{2}$ value of $14 \%$, which explains the dependent variable more than $1^{\text {st }}$ and $2^{\text {nd }}$ models. The independent variable with ROA in model 3 is also insignificant by having a pvalue of 0.182 and $a \mathrm{z}$ value of 1.34 . The coefficient value is 0.045 that represents a positive relationship between discretionary accruals and ROA. This indicates that if discretionary accruals increased by $1 \%$, ROA is increased by $4.5 \%$ as the coefficient value is positive. This means that a higher level of earnings management practices measured by discretionary accruals is associated with a higher level of ROA, thus lowering the FRQ. This ultimately explains a weaker positive relationship with Financial Reporting Quality.

Most of the control variables of model 3 designate a significant relationship with ROA. Debt to Equity ratio, which is the measure of leverage, has a p-value of 0.009 and a coefficient value of -0.001 . This suggests that there is a negative relationship between leverage and ROA. Meaning higher leverage lowers the ROA. Risk has a coefficient -0.018 and a p-value of 0.026. Also, EY and PC audit firms have $\mathrm{p}$ values of 0.075 and 0.958 , respectively.

In summary, there is no statistically significant relationship between financial Reporting Quality and Firm performance in Sri Lankan context. Because although the overall models are significant. None of the dependent variables, ROE, Market to Book Ratio and ROA show a significant relationship with the financial reporting quality.

\section{CONCLUSION AND DISCUSSION}

Based on the results, it can be concluded that Financial Reporting Quality measured by
Discretionary accruals does not have a statistical significance impact to the financial performance measures such as Return of Equity, Market to Book ratio, and Return on Assets of listed companies in Sri Lanka. However, the overall three models were statistically significant when considering the relationship with the control variables.

When discussing the analysis results and the developed hypotheses, all three of the hypotheses have been rejected as mentioned in Chapter 4. All the hypotheses were developed to assess the significant relationship. Since all three models were not significant, the developed alternative hypotheses must be rejected by accepting the null hypotheses.

Supportive to this result, there is research, which has provided the same results. Moshi (2016) showed that Return nn Assets has an insignificant positive association with earning management measured by discretionary accruals in manufacturing companies listed at the Dar-es-salaam stock exchange market under correlation and regression analysis.

Likewise, Ezeagba (2018) states that earnings management which is the inverse of Financial Reporting Quality, has a negative but insignificant effect on the performance of corporate firms, which was estimated by Return On Shareholders' Fund (ROSF), Return On Capital Employed (ROCE), net profit after tax and Return On Assets (ROA).

Also, The Relationship between Financial Reporting Quality and Corporate Performance in Iran context was carried out by Dashtbayaz, Hedayatipour \& Molaviwas (2018). There was no relationship found between the different criteria of Financial Reporting Quality and corporate performance.

According to Pakianathan (2017), there is an insignificant positive relationship between firm growth measured using Market to Book ratio has an insignificant positive relationship with discretionary accruals while firm performance also has higher positive correlation but insignificant relationship with insignificant discretionary accruals reported under random effect model. 
However, this study's findings contradict conclusions that resulted in a significant relationship in previous studies (García-Lara et al., 2010; Ahmed and Duellmand, 2011; Bushman and Smith, 2001; Martínez-Ferrero 2014) that were discussed under literature review section.

Finally, it can be concluded that there is no statistical significance found when examining the impact of Financial Reporting Quality on Firm Performance in Sri Lankan listed companies.

Based on the regression analysis results of this study, the findings are useful to investors, managers and shareholders when making decisions using both financial and nonfinancial information. However, as the results was not statistically significant, the following recommendations can be made for further research.

As the sample of this study is limited to 30 listed companies over 6 years, it is recommended for future research to increase the sample size by extending the study period and the number of companies.

Further, it is recommended to use more proxies like accruals quality and accounting conservatism as the measurement of Financial Reporting Quality to evaluate it in different perspectives.

In addition to the financial performance measures such as ROE, ROA and MTB were used in this study. Future research can use firm value as well as non-financial performance aspects of the firm.

\section{REFERENCES}

Ahmed, A. S. (2011). Evidence on the role of accounting conservatism in monitoring managers' investment decisions. Accounting and Finance, 51(3).

Asegdew, K. (2016). Determinants of financial reporting quality: Evidence from large manufacturing share companies of Addis Ababa. Addis Ababa University.

Atu, O. O. K., Atu, F. O., Enegbe, O. P., \& Atu, E. C. (2016). Determinants of earnings management in Nigerian quoted companies. Igbinedion University Journal of Accounting, 1, 118-133.

Bens, D. A., Nagar, V., \& Wong, M. F. (2002). Real investment implications of employee stock option exercises. Journal of Accounting Research, 40(2), 359-393.

Boone, J. P., Khurana, I. K., \& Raman, K. K. (2012). Audit market concentration and auditor tolerance for earnings management. Contemporary Accounting Research, 29(4), 1171-1203.

Bushman, R. .. (2001). Financial accounting information and corporate governance. Journal of Accounting and Economics, 32, 237-333.

C.A.Kankanamage, K. S. (2015). The impact of audit committee to enhance the financial reporting quality and transparency: Evidence from srilankan listed firms.

Chen, H. Q. (2011). The role of international financial reporting standards in accounting quality: Evidence from the European Union. Journal of International Financial Management and Accounting, 21(3), 22078.

Choi, T. H., \& Pae, J. (2011). Business ethics and financial reporting quality: Evidence from Korea. Journal of Business Ethics, 103(3), 403-427.

Dechow, P. M., \& Skinner, D. J. (2000). Earnings management: Reconciling the views of accounting academics, practitioners, and regulators. Accounting horizons, 14(2), 235-250.

Dechow, P. M., \& Dichev, I. D. (2002). The quality of accruals and earnings: The role of accrual estimation errors. The accounting review, 77(s-1), 35-59.

Ehioghiren, E. E., \& Atu, O. O. K. (2016). Forensic accounting and fraud management: Evidence from Nigeria. Igbinedion University Journal of Accounting, 2(8), 245-308.

Ezeagba, C. E., \& Abiahu, M. F. C. (2018). 
Influence of professional ethics and standards in less developed countries: an assessment of professional accountants in Nigeria. Asian Journal of Economics, Business and Accounting, 6(1), 1-9.

Ferdinand Siagian, S. V. (2013). Corporate governance,reporting quality, and firm value: evidence from Indonesia. Indonesia Journal of Accounting in Emerging Economics, 4-20.

García Lara, J. M., Garcia Osma, B., \& Mora, A. (2005). The effect of earnings management on the asymmetric timeliness of earnings. Journal of Business Finance \& Accounting, 32(3-4), 691-726.

Gunny, K. (2005). What are the Consequences of Real Earnings Management. Academy of Accounting and Financial Studies Journal, 22(1), 1-18.

Hassan, S. \&. (2013). Firm characteristics and financial reporting quality of listed manufacturing firms in Nigeria. International Journal of Accounting, Banking and Management, 47-63.

Hillman, A. J., \& Keim, G. D. (2001). Shareholder value, stakeholder management, and social issues: what's the bottom line?. Strategic management journal, 22(2), 125-139.

ICASL. (2020). Conceptual framework for financial reporting.

Jo, H., \& Kim, Y. (2007). Disclosure frequency and earnings management. Journal of Financial Economics, 84(2), 561-590.

Jonas, G. J., \& Blanchet, J. (2000). Assessing quality of financial reporting. Accounting horizons, 14(3), 353.

Kankanamage, C. A., \& Aruna Shantha, K. V. (2015). The impact of audit committee to enhance the financial reporting quality and transparency: Evidence from Sri Lankan listed firms.

King'wara.R.A. (2015). Effect of IRFRS adoption on reporting qulity in kenya. jounal of Business management, 17(1), 8284.

Kithinji, J. G., Oluoch, W., \& Mugo, R. (2014). What Is the Effect of Rights Issue on Firms Share Performance in the Nairobi Securities Exchange?.

Kothari, S. L. (2005). Performance matched discretionary accrual measures. Journal of Accounting and Economics, 39(1), 163197.

Lambert, R. L. (2007). Accounting information, disclosure, and the cost of capital. Journal of Accounting Research, 45(2), 385-420.

Lee, C. H. (2006). Performance, growth and earnings management. 11, 305-334.

Lin, Z., Jiang, Y., Tang, Q., \& He, X. (2014). Does high-quality financial reporting mitigate the negative impact of global financial crises on firm performance? Evidence from the United Kingdom. Australasian Accounting, Business and Finance Journal, 8(5), 19-46.

Lari Dashtbayaz, M., Hedayatipour, M., \& Molavi, H. (2018). The Relationship between Financial Reporting Quality and Corporate Performance: Evidence from Iran. Iranian Journal of Accounting, Auditing and Finance, 2(2).

Lopes, C. C. (2012). The Financial Reporting Quality Effect on European Firm Performance. Available at SSRN 2179994. SSRN Electronic Journal.

Mahoney, L. L. (2008). Corporate Social Performance, Financial Performance for Firms that Restate Earnings. Issues in Social and Environmental Accounting, 104-130.

Martínez-Ferrero, J. (2014). Consequences of financial reporting quality on corporate performance: Evidence at the international level. Estudios de Economía, 41(1), 49-88.

Matundura, E. (2014). The effects of Public Capital Expenditure on Economic Growth in Kenya (Doctoral dissertation, Moi 


\section{University).}

Mironiuc, M., Carp, M., \& Chersan, I. C. (2015). The relevance of financial reporting on the performance of quoted Romanian companies in the context of adopting the IFRS. Procedia Economics and Finance, 20, 404-413.

Mitton, T. (2002). A cross-firm analysis of the impact of corporate governance on the East Asian financial crisis. Journal of financial economics, 64(2), 215-241.

McDermott, K. E. (2011). Financial Reporting Quality and Investment in Corporate Social Responsibility.

Morris, R., Susilowati, I., \& Gray, S. (2012, August). "The Impact of IFRS Adoption versus Non-Adoption on Corporate Disclosure Levels in the Asian Region". In American Accounting Association Annual Meeting and Conference on Teaching and Learning in Accounting, Washington DC. Retrieved from http://aaahq. org/AM2012/display. cfm.

Moshi, J. A. (2016). Impact of earnings management on firm's performance: a case study of manufacturing companies listed at the dar-es-salaam stock exchange market.

Nijam, H. (2016). Impact of IFRS adoption in Sri Lanka: An evaluation of financial reporters' perception. International Journal of Managerial and Financial Accounting.

Nnadi, M. (2013). International Financial Reporting Standards (IFRS) and Financial Reporting Quality in Emerging Economies: Evidence from China and Hong Kong. available on-line at: http://www. virtusinterpress. org/IMG/pdf/Matthias_Nnadi_pa per. pdf, 14.

Ouma, V. (2017). The relationship between reporting quality and financial performance of companies listed at Nairobi Securities Exchange (Doctoral dissertation, University of Nairobi).

Pakianatha, A. E. (2017). Audit quality and its impact on the degree of earnings management: evidence from sri lanka.

Perera, T. Y. (2019). The Impact of IFRS Adoption on Quality of Accounting Information: Evidence from Sri Lanka. Kelaniya Journal of Management, 8(1).

Prior, D. S. (2008). Are socially responsible managers really ethical? Exploring the relationship between earnings management and corporate social responsibility. Corporate Governance: An International Review, 16(3), 160-177.

Rajgopal, S., \& Venkatachalam, M. (2011). Financial reporting quality and idiosyncratic return volatility. Journal of Accounting and Economics, 51(1-2), 1-20.

Richardson, V. J. (1998). Information Asymmetry and Earnings Management: Some Evidence. http. ssrn. com. https://doi. org/10.2139/ssrn, 83868 .

Schipper, K. (1989). Earnings management. Accounting horizons, 3(4), 91.

Shireenjit K. Johl, S. K. (2013). Internal audit function, board quality and financial reporting quality: evidence from Malaysia. Managerial Auditing Journal, 28(9), 780814.

Toukabri, M., Jilani, P. F., \& Jemâa, O. B. (2014). The interaction between environmental accounting practices and earnings management. Journal of Business Studies Quarterly, 5(3), 99.

Waddock, S. A. (1997). Corporate Social Performance-Financial Performance Link. Strategic Management Journal, 303-319.

Weerathunga, P. R. (2015). The Impact of International Financial Reporting Standards adoption on Accounting Quality: Evidence From Sri Lanka (Doctoral dissertation).

Yasas, T. G., \& Perera, H. A. P. L. (2019). The impact of IFRS adoption on quality of accounting information: evidence from Sri Lanka. Kelaniya journal of management, 8(1). 